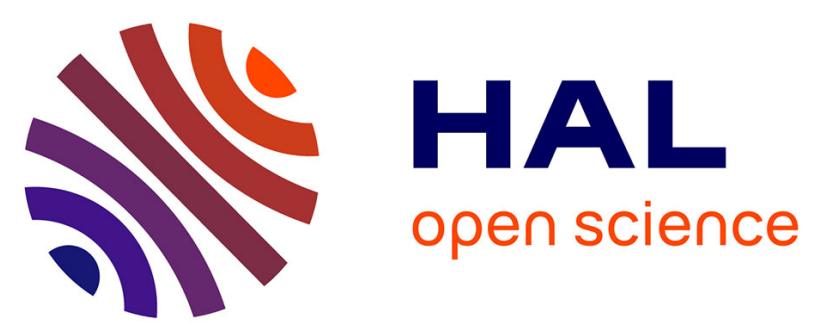

\title{
A new Triassic shortening-extrusion tectonic model for Central-Eastern Asia: Structural, geochronological and paleomagnetic investigations in the Xilamulun Fault (North China)
}

\author{
Pan Zhao, Michel Faure, Yan Chen, Guanzhong Shi, Bei Xu
}

\section{To cite this version:}

Pan Zhao, Michel Faure, Yan Chen, Guanzhong Shi, Bei Xu. A new Triassic shortening-extrusion tectonic model for Central-Eastern Asia: Structural, geochronological and paleomagnetic investigations in the Xilamulun Fault (North China). Earth and Planetary Science Letters, 2015, 426, pp.46-57. 10.1016/j.epsl.2015.06.011 . insu-01168054

\section{HAL Id: insu-01168054 https://hal-insu.archives-ouvertes.fr/insu-01168054}

Submitted on 25 Jun 2015

HAL is a multi-disciplinary open access archive for the deposit and dissemination of scientific research documents, whether they are published or not. The documents may come from teaching and research institutions in France or abroad, or from public or private research centers.
L'archive ouverte pluridisciplinaire HAL, est destinée au dépôt et à la diffusion de documents scientifiques de niveau recherche, publiés ou non, émanant des établissements d'enseignement et de recherche français ou étrangers, des laboratoires publics ou privés. 
A new Triassic shortening-extrusion tectonic model for Central-Eastern Asia: structural, geochronological and paleomagnetic investigations in the Xilamulun Fault (North China)

Pan Zhao ${ }^{1,2}$, Michel Faure ${ }^{2,3}$,Yan Chen ${ }^{2,3}$, Guanzhong Shi ${ }^{1,2}$ and Bei $\mathrm{Xu}^{1, *}$

${ }^{1}$ Key Laboratory of Orogenic Belts and Crustal Evolution, Ministry of Education,

Peking University, Beijing, 100871, China

${ }^{2}$ Université d'Orléans, ISTO, UMR 7327, 45071 Orléans, France

${ }^{3}$ CNRS/INSU, ISTO, UMR 7327, 45071 Orléans, France

*Corresponding author E-mail address: $\underline{\text { bxu@pku.edu.cn }}$ 
Abstract:

At the northern margin of the North China Block (NCB), the Xilamulun Fault $(\mathrm{XMF})$ is a key belt to decipher the tectonic evolution of Central-Eastern Asia, as it records the Paleozoic final closure of the Paleo-Asian Ocean, and localizes a Late Triassic intracontinental deformation. In this study, structural analysis, ${ }^{40} \mathrm{Ar}-{ }^{39} \mathrm{Ar}$ dating, and paleomagnetic studies were performed to investigate the kinematics of the $\mathrm{XMF}$ and to further discuss its Triassic geodynamic significance in the Central-Eastern Asia framework after the Paleozoic Central Asian Orogenic evolution. The structural analyses reveal two phases of ductile deformation. The first one (D1), which displays N-verging and E-W trending folds, is related to the Early Paleozoic collisional event between the NCB and the Songliao-Hunshandake Block (SHB). The second phase (D2) displays a high-angle foliation and a pervasive subhorizontal E-W stretching lineation with kinematic criteria indicative of dextral strike-slip shearing. The ${ }^{40} \mathrm{Ar}^{39} \mathrm{Ar}$ dating on mylonitic granite places the main shearing event around 227-209 Ma. This D2 shearing is coeval with that of the dextral strike-slip Bayan Obo-Chifeng Fault (BCF) and the Chicheng-Fengning-Longhua Fault to the south, which together constitute a dextral shearing fault system on the northern margin of the NCB during the Late Triassic. The paleomagnetic study performed on the Middle Permian Guangxingyuan pluton, located between the XMF and BCF, documents a local clockwise rotation of this pluton with respect to the NCB and SHB. Our multidisciplinary study suggests a NNW-SSE shortening and strike-slip shearing dominated tectonic setting on the northern margin of the NCB during the Late Triassic. 
Combining the contemporaneous dextral strike-slip movements of the XMF and BCF in northern China and the sinistral strike-slip movement of East Gobi Fault (EGF) in southeastern Mongolia with the large-scale tectonic framework, a Late Triassic NNW-SSE shortening-eastward extrusion tectonic model for Central-Eastern Asia is firstly proposed. The NNW-SSE shortening results in the eastward extrusion of the continental wedge bounded by the BCF and EGF, which is accommodated by the different kinematic patterns of the southern (XMF and BCF) and northwestern (EGF) bounding faults. This shortening-extrusion tectonic framework is tentatively interpreted as the result of the far field forces associated with three Late Triassic lithosphere-scale convergences in East Asia: i) northward intracontinental subduction between the NCB and South China Block, ii) collision of the Qiangtang Block with the Qaidam Block, and iii) southward subduction of the Mongol-Okhotsk Ocean beneath the Mongolia Block.

Keywords: Xilamulun Fault; dextral strike-slip shearing; local rotation; Late Triassic; Central-Eastern Asia; shortening-extrusion model

\section{Introduction}

Central-Eastern Asia, located between the North China Block (NCB) and Tarim Block in the south and the Siberian Block (SIB) in the north, recorded the Neoproterozoic to Paleozoic evolution of the Central Asian Orogenic Belt (CAOB; e.g. Sengör et al., 1993; Xiao et al., 2003; Xu et al., 2013). After the end of the CAOB 
formation that resulted in the amalgamation of the NCB, Tarim Block, SIB and several intervening microcontinents, intracontinental strike-slip faults were the prominent tectonic features of Central-Eastern Asia during the Early Mesozoic (Lamb et al., 1999; Johnson, 2004; Webb and Johnson, 2006; Webb et al., 2010; Zhao et al., 2013). The strike-slip faults can be ascribed to the consequence of several tectonic events, such as the Mesozoic closure of the Mongol-Okhotsk Ocean (Zonenshain et al., 1990; Meng, 2003), the Meso-Cenozoic Pacific plate subduction (Wang et al., 2011), and the far-field effects of the Triassic NCB - South China Block (SCB) intracontinental convergence (Rowley et al., 1997; Liu et al., 2006). The strike-slip faults are critical structures in understanding the post-Paleozoic intracontinental deformation, especially for the evolution of the former tectonic sutures, which are potentially susceptible to reactivation if post-collisional intracontinental deformation occurs (Laurent-Charvet, 2003; Cogné et al., 2005; Choulet et al., 2013).

Inner Mongolia of China exposes both the northern margin of the NCB, and the southeastern part of the CAOB (Fig. 1a; Enkin et al., 1992; Xiao et al., 2003; Xu et al., 2013). Concerning its Phanerozoic tectonic evolution, three episodes are well recognized. (1) During the Early Paleozoic, these geological units experienced several $\mathrm{N}-\mathrm{S}$ ductile shearing phases, corresponding to two orogenic events, namely i) the Late Silurian collision between the NCB and the Songliao-Hunshandake Block, and ii) the Late Devonian collision between the Songliao-Hunshandake Block and the Xing'an-Airgin Sum Blocks (Tang, 1990; Shi et al., 2013; Xu et al., 2013; 2015). (2)

A Carboniferous-Permian post-orogenic extensional setting is documented by 
Carboniferous clastic-carbonate deposits, Permian intrusions and volcanic-sedimentary sequences (Tang, 1990; Zhang et al., 2008; Zhao et al., 2015). These rocks did not record any synmetamorphic ductile deformation, only tilting and folding. However, the significance of this episode is controversial, since some granitic intrusions present magmatic arc affinities and the mafic-ultramafic rocks are considered as ophiolite (Chen et al., 2000; Li, 2006; Zhang et al., 2009). (3) A Late Jurassic-Early Cretaceous episode is characterized by extensional tectonics with rift basins, metamorphic core complexes (MCC), and magmatism (Meng, 2003; Wu et al., 2005; Wang et al., 2012).

However, as few Triassic-Early Jurassic strata or magmatic rocks are exposed, the Early Mesozoic evolution is still not well understood. Meanwhile, the Early Mesozoic is a crucial period in deciphering the tectonic transition from Paleozoic evolution of the CAOB to the Late Mesozoic extension (Meng, 2003). An important Middle-Late Triassic thermal-tectonic event has been identified in southeastern Mongolia and Chinese Inner Mongolia (Daoudene et al., 2012); however, its geodynamic mechanism is not clear (Chen et al., 2000; Wang et al., 2004; Li et al., 2007; Liu et al., 2012). Nevertheless, the Triassic strike-slip faults that control the regional tectonics of this period are well recognized in the neighbouring areas of the Southern Mongolia (Lamb et al., 1999; Webb et al., 2010) and Junggar (Laurent-Charvet et al., 2003; Choulet et al., 2013). Several Early Mesozoic strike-slip faults on the northern margin of the NCB were described preliminarily, e.g., Xilamulun Fault, Hongshan-Balihan Fault, and Chicheng-Fengning-Longhua Fault 
(Wang et al., 2013), giving us a good opportunity to study the Early Mesozoic kinematics in this area. Among these faults, the Xilamulun Fault was considered as the suture zone of the final closure of the Paleo-Asian Ocean during the Late Paleozoic (Li et al., 2006; Li et al., 2014). Furthermore, the Early Mesozoic reactivation and deformation along this fault can give important clues to decipher the Early Mesozoic tectonic evolution of the northern margin of NCB. Hence, in this study, a multi-disciplinary approach, involving structural analysis, ${ }^{40} \mathrm{Ar}-{ }^{39} \mathrm{Ar}$ dating, and paleomagnetic studies, was performed in order to investigate the kinematics and timing of the Xilamulun Fault and to discuss its place in the Early Mesozoic tectonic framework of Central-Eastern Asia.

\section{Geological setting}

\subsection{Central-Eastern Inner Mongolia}

The tectonic framework of Central-Eastern Inner Mongolia is characterized by two Early-Middle Paleozoic orogenic belts (Fig. 1b; Xu et al., 2013). The Southern Orogen (SO), from Bayan Obo via Ondor Sum to the Xilamulun Fault (Fig. 1b), is characterized from $\mathrm{S}$ to $\mathrm{N}$ by an Early Paleozoic magmatic arc (Jian et al., 2008) and a subduction-accretionary complex enclosing a $\sim 450$ Ma high pressure blueschist (De Jong et al., 2006). The subduction-accretionary complex experienced top-to-the-north ductile shearing along a flat-lying foliation (Shi et al., 2013). Late Silurian molassic deposits unconformably overlie these litho-tectonic units (Tang et al., 1990). The Northern Orogen (NO), developing from Sunidzuoqi through Xilinhot to 
West-Ujimqin, is characterized from $\mathrm{N}$ to $\mathrm{S}$ by an Early Paleozoic magmatic arc (Jian et al., 2008) and a subduction-accretionary complex, with blocks of basaltic lava that underwent a $\sim 380$ Ma blueschist facies metamorphism (Xu et al., 2001; Fig. 1b). Top-to-the-south ductile and syn-metamorphic shearing was documented for the subduction-accretionary complex (Xu et al., 2013). Late Devonian terrigenous series unconformably overlies the older litho-tectonic units (Tang, 1990; Xu et al., 2013). Between the SO and the NO, Precambrian basement, called the Songliao-Hunshandake Block (SHB; Fig. 1b), has been identified by Proterozoic meta-diorite and meta-gabbro yielding zircon $\mathrm{U}-\mathrm{Pb}$ ages of $1839 \pm 7 \mathrm{Ma}$ and $1808 \pm$ $21 \mathrm{Ma}$, respectively (Wang et al., 2006; Pei et al., 2007). Cambrian-Middle Silurian meta-sedimentary and meta-volcanic rocks, referred to as the Ondor Sum Group, represent the sedimentary cover of the SHB. These rocks were deformed during the Silurian-Devonian orogenic events (Xu et al., 2013). Following deposition of Devonian molasse, the lithological succession is dominated by Carboniferous shallow marine clastic-carbonate deposits, Early-Middle Permian volcanic-sedimentary sequences, and Late Permian fluvial conglomerate-sandstone and lacustrine black shale (Tang, 1990; Mueller et al., 1991). The Late Paleozoic rocks are undeformed except along narrow E-W or NE-SW striking shear zones, such as those observed near Erenhot, East Ujimqin, and along the Xilamulun River (Fig. 1b).

\subsection{Xilamulun Fault}

The Xilamulun (or Xar Moron River) Fault, located at the northern margin of the NCB (Fig. 1b), is considered as the suture zone between the North China Block 
and the Siberia Block (Tang, 1990; Li, 2006). It is also the controlling fault for the Mesozoic Mo-Cu metallogenic belt (Zhang et al., 2009; Wu et al., 2011; Zeng et al., 2013). The Xilamulun Fault extends about $700 \mathrm{~km}$ from Hexigten east to Changchun, which is documented by both geological (Li, 2006) and geophysical evidence, such as aeromagnetic and gravity anomalies and a magnetotelluric profile (Liu et al., 2008; Chen et al., 2008). The eastern part of the Xilamulun Fault (east of $119^{\circ} \mathrm{E}$ ) is hidden by desert sands and Cenozoic sediments, hence the western segment, which is well exposed from Hexigten to Balianqiao (Figs. 1b and 2a), was chosen as target for this study.

Along the Xilamulun River, a $\sim 15 \mathrm{~km}$-wide shear zone is represented by three sub-parallel strike-slip faults (Fig. 2). Of these three faults, the Xilamulun Fault is the best exposed one. The geological units along these strike-slip faults exhibit a pervasive ductile deformation. From a litho-stratigraphic point of view, the Xilamulun area exposes the following succession in ascending order (IMBGMR, 1991). The Ordovician-Early Silurian (O-S $\mathrm{S}_{1}$ Shuangjingzi complex (Fig. 2a) is mainly composed of schist, mylonite, and volcanic-sedimentary rocks. An Early-Middle Permian volcanic-sedimentary sequence unconformably overlies the Early Paleozoic Shuangjingzi complex (Fig. 2). The Late Permian sequence is represented by $\sim 4$ km-thick fluvial conglomerate and lacustrine black shale with abundant plant fossils (Mueller et al., 1991; IMBGMR, 1991). After the Late Permian, the whole area came into a terrestrial environment, and deposition was absent until the Jurassic continental volcanic-sedimentary deposits (Meng, 2003). Three episodes of intrusion have been 
identified in the Xilamulun area (Fig. 2a). The Early-Middle Permian granites and granodiorites, yielding zircon U-Pb ages of 285-265 Ma (Li et al., 2007; Li et al., 2014), crop out on both sides of the Xilamulun River (Fig. 2a). Granitic plutons of Permian age are strongly deformed (Li et al., 2014). The Triassic granitic pluton, which was dated at 237-229 Ma, intruded into the mylonite-gneiss complex (Fig. 2a; Li et al., 2007). The margin of this pluton shows obvious E-W striking foliation and subhorizontal lineation, but undeformed granite is recognized in the central part (Fig. 2a; Li et al., 2007). Lastly, undeformed Early Cretaceous granites intruded into the older rocks, especially the $\mathrm{O}-\mathrm{S}_{1}$ Shuangjiangzi complex and the Late Permian series (Fig. 2a; Wu et al., 2005).

3. Structural analysis of the Xilamulun Fault

Our field observations around the Xilamulun Fault enable us to decipher two main ductile deformation events, namely a north verging folding (D1) and an E-W dextral shearing (D2).

The D1 event can only be observed in the $\mathrm{O}-\mathrm{S}_{1}$ volcanic-sedimentary rocks (Fig. 2a). It is represented by meter to hectometer scale tight folds with an E-W striking axis and southward dipping axial plane (Figs. 3a), indicating a top-to-the-north vergence (Fig. 2b).

The microstructure resulting from the D2 event is pervasively developed along the Xilamulun Fault. It can be observed in the mylonite that developed at the expense of the $\mathrm{O}-\mathrm{S}_{1}$ volcanic-sedimentary rocks, Early-Middle Permian volcanic and granitic 
rocks, and in the Triassic granites (Figs. 2a and 2b). In the field, subvertical cliffs, which can be observed along the Xilamulun River, often exhibit horizontal slicken lines and thus correspond to fault planes (Fig. 3b). The horizontal slicken lines, steps, and riedel shears developed on and adjacent to these vertical fault planes indicate a dextral sense of shearing. Near the fault, a sub-vertical mylonitic foliation contains a sub-horizontal stretching lineation, which is represented by elongated quartz rods or feldspar aggregates (Figs. 2c and 3c-3e). Dextral shearing can be observed at both the outcrop and thin section scale. At the outcrop-scale, the dextral criteria include asymmetric fold with vertical axis (Fig. 3e), centimeter-scale asymmetric $\sigma$-type feldspar and quartz grains (Fig. 3f), and S-C fabrics (Fig. 3g). In thin section, classical shear criteria, such as millimeter-scale asymmetric $\sigma$-type quartz grains (Fig. $3 \mathrm{~h}$ ), quartz grains with asymmetric pressure shadows of quartz and biotite (Fig. 3i), and muscovite "mica fish" structures (Fig. 3j) confirm the dextral sense of shear.

In summary, the Xilamulun strike-slip fault ductilely deformed all the pre-Jurassic geological units, developing a planar-linear mylonitic fabric in the $\mathrm{O}-\mathrm{S}_{1}$ Shuangjingzi volcanic-sedimentary rocks, Early Permian volcanic rocks, Early-Middle Permian granitic plutons and Middle-Late Triassic granite (Fig. 4). All of these rocks are characterized by high-angle inclined foliations and E-W sub-horizontal lineations yielding dextral kinematic indicators. The Middle Jurassic unconformity and Early Cretaceous undeformed granites post-date the ductile shearing (Fig. 4). Therefore, the strike-slip movement of the Xilamulun Fault occurred between the Late Triassic and Early Jurassic. In order to constrain the timing 
of slip on the Xilamulun Fault, ${ }^{40} \mathrm{Ar} /{ }^{39} \mathrm{Ar}$ age determination has been carried out on the mylonitic granite.

4. ${ }^{40} \mathrm{Ar} /{ }^{39} \mathrm{Ar}$ geochronology

One mylonitic granite sample (J11B, GPS: $\left.43^{\circ} 17^{\prime} 34^{\prime \prime} \mathrm{N}, 118^{\circ} 21^{\prime} 38^{\prime \prime} \mathrm{E}\right)$ was collected from the northern bank of the Xilamulun River during our fieldwork in order to constrain the shearing age. After a coarse crushing, syn-kinematic muscovite was extracted from the sample as the target mineral for ${ }^{40} \mathrm{Ar} /{ }^{39} \mathrm{Ar}$ dating. Mineral grains together with Bern4-Ms (used for neutron monitoring) and $\mathrm{K}_{2} \mathrm{SO}_{4}, \mathrm{CaF}_{2}$, and $\mathrm{KCl}$ (used for $\mathrm{K}, \mathrm{Ca}$, and $\mathrm{Cl}$ isotopic revising), were irradiated in the $\mathrm{H} 8$ canal in 49-2 nuclear reactor at the China Institute of Atomic Energy (CIAE, Beijing), for 6 hours and 20 minutes. The minerals were then analysed by the automatic, high-precision and high-resolution laser microprobe ${ }^{40} \mathrm{Ar} /{ }^{39} \mathrm{Ar}$ dating system in the Laboratory of Orogenic and Crustal Evolution (LOCE), Peking University (China). The procedures for isotope analyses and age calculations were controlled by MassSpec software. The parameters used for analyses and testing procedures can be found in Gong et al. (2012).

The analytic results are presented in Supplementary Table 1 and the ${ }^{40} \mathrm{Ar} /{ }^{39} \mathrm{Ar}$ inverse isochron is shown in Figure 5. Step-heating of muscovite from this sample yielded an apparent age spectrum, with an argon loss profile and gave minimum and maximum ages of 131 and 207 Ma, respectively (Fig. 5a). Furthermore, an isochron

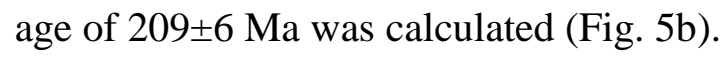




\section{Paleomagnetic constraints}

In order to quantify the displacement along the Xilamulun Fault and the regional rotation related to this strike-slip fault, a paleomagnetic study was carried out on the Middle Permian (263 \pm 3 Ma, Jiang et al., 2011; 266 \pm 1 Ma, Zhao et al., in preparation) Guangxingyuan granodiorite pluton, which is located $20 \mathrm{~km}$ to the south of the Xilamulun Fault (Figs. 1b and 6a). This $15 \mathrm{~km}$ long and $10 \mathrm{~km}$ wide pluton consists of medium to coarse grained granodiorite with dioritic enclaves. This pluton intruded into the Early Permian volcanic-sedimentary series, causing contact metamorphism at the margin. Neither visible deformation nor metamorphism can be observed in this pluton. Seven paleomagnetic sites have been collected with seven to ten cores drilled in each site by a portable gasoline drill. The cores were orientated by magnetic and solar compasses when it was possible. The average difference between these two azimuths is $1.6^{\circ} \pm 3.3^{\circ}$. This value was used to correct the cores that have been only magnetically oriented. Magnetic mineralogical investigation and stepwise demagnetization were carried out at the Laboratoire de Magnétisme des Roches d'Orléans (LMRO) and the Laboratoire de Paleomagnétisme of Institut de Physique du Globe de Paris (IPGP) at Saint Maur (France). The detailed experiment procedures and data analysis processes can be found in Zhao et al. (2013).

\subsection{Magnetic mineralogy}

Three kinds of magnetic mineralogical experiments have been carried out, the results of which are presented in Figure 6. Thermomagnetic measurements show a 
sharp drop of magnetic susceptibility at $585{ }^{\circ} \mathrm{C}$ (Fig. 6b), revealing characteristic of titanium-poor magnetite. The isothermal remanent magnetization (IRM) measurements display an abrupt increase, with total saturation at about $200 \mathrm{mT}$ (Fig. 6c), indicating predominantly low-coercitive magnetic minerals. Hysteresis loops show a particularly narrow-waisted sigmoidal shape (Fig. 6d), which suggests typical low magnetic coercitive magnetite. Overall, the magnetic mineralogical experiments identified titanium-poor magnetite as the main magnetic remanent carrier.

\subsection{Paleomagnetic direction}

The granodiorite displays high natural remanent magnetization (NRM) intensities ranging from 100 to $4550 \mathrm{~mA} / \mathrm{m}$, with an average of $532 \mathrm{~mA} / \mathrm{m}$. Both single- and dual-components were isolated after stepwise demagnetization (Figs. 7a-7c). The low temperature components (LTC) for dual-component specimens, up to $350-450{ }^{\circ} \mathrm{C}$, present scattered directions (Figs. $7 \mathrm{~b}$ and $7 \mathrm{c}$ ). After removing the dispersed LTC, the high temperature components (HTC) display directions that are consistent with those of the single-component specimens; and both normal (Figs. 7a and 7b) and reversed (Fig. 7c) polarities can be observed (Supplementary Table 2). Consequently, a mean direction of the HTC for the Guangxingyuan granodiorite pluton was calculated from 7 sites: $\mathrm{D}=30^{\circ}, \mathrm{I}=29.4^{\circ}, \mathrm{k}=126.1, \alpha_{95}=5.4^{\circ}($ Fig. $7 \mathrm{~d})$.

\section{Discussion}

Our structural, geochronological and paleomagnetic investigations presented above allow us to discuss the characteristics of the Xilamulun Fault and its 
implication for the Triassic tectonic evolution of Central-Eastern Asia.

\subsection{Age constrains of deformation along the Xilamulun Fault}

The Xilamulun Fault (Fig. 1b) was considered a Paleozoic suture, along which north-verging folds were developed related to the subduction of the Paleo-Asian Ocean beneath the northern margin of the NCB (Tang and Yan, 1993; Xu et al., 2013). The southward subduction and subsequent orogenic event produced an E-W trending fold belt with mainly southward dipping axial planes (Shi et al., 2013), which is consistent with the D1 north-verging folds observed in the $\mathrm{O}-\mathrm{S}_{1}$ volcanic-sedimentary rocks. The deformation age of this fold complex is well constrained by the radiometric age of metamorphic rocks and pegmatitic dykes. The ${ }^{40} \mathrm{Ar} /{ }^{39} \mathrm{Ar}$ dating results of the blueschist-facies quartzite mylonites range from 453 to $426 \mathrm{Ma}$ (Tang and Yan, 1993; De Jong et al., 2006), which supports the age of the D1 deformation. Furthermore, an undeformed pegmatitic dyke intruded this fold complex in the Ondor Sum area to the west and yielded a zircon $\mathrm{U}-\mathrm{Pb}$ age of $411 \mathrm{Ma}$, which postdates the collision and the related D1 deformation (Zhang et al., 2013).

Along the Xilamulun Fault, the ductile strike-slip shearing (D2) can be observed in all pre-Jurassic units within the fault zone (Fig. 4). Our ${ }^{40} \mathrm{Ar} /{ }^{39} \mathrm{Ar}$ dating of muscovite from the granitic gneiss gives an isochron age of $209 \pm 6 \mathrm{Ma}$, constraining the latest increment of dextral strike-slip movement to the Late Triassic. Moreover, several muscovite ${ }^{40} \mathrm{Ar} /{ }^{39} \mathrm{Ar}$ ages from mylonite and granitic gneiss along the Xilamulun Fault have been published with consistent ages of 227-221 Ma (Ma, 2009). These thermo-chronologic results successfully constrain the strike-slip movements of 
the Xilamulun Fault to the Late Triassic. Meanwhile, the Triassic granite along the Xilamulun Fault yielded zircon U-Pb age of 237-229 Ma and displayed the same E-W shearing deformation ( $\mathrm{Li}$ et al., 2007), implying that emplacement of this syn-kinematic pluton was related to the strike-slip shearing along the Xilamulun fault. 6.2 Triassic strike-slip fault system at the northern margin of the NCB

At the northern margin of the NCB, two main E-W dextral strike-slip faults, the Xilamulun Fault (XMF) and the Bayan Obo-Chifeng Fault (BCF), control the regional tectonic framework (Fig. 8a). The XMF, considered to be the suture zone between the NCB and SHB, was reactivated in the Late Triassic by dextral strike-slip movements. The E-W trending BCF was also a dextral strike-slip fault (Wang et al., 2013). The muscovite and biotite ${ }^{40} \mathrm{Ar} /{ }^{39} \mathrm{Ar}$ ages of mylonitized granite and carbonate mylonite from western (Kangbao-Weichang areas) and eastern (Faku area) parts of the BCF reveal two phases of dextral shearing in the Middle-Late Permian (269-255 Ma; Wang et al., 2013), and the Late Triassic (Fig. 8a; 231-219 Ma; Zhang et al., 2005). In addition to these two large-scale tectonic controlling faults, several secondary strike-slip faults were identified. For instance, the Chicheng-Fengning-Longhua Fault (Fig. 8a) in the south shows two phases of ductile dextral shearing, which are Middle Permian-Early Triassic (263-243 Ma) and Late Triassic (237-233 Ma; Hu et al., 2003; Wang et al., 2013) in age, followed by a brittle episode in the Jurassic (Faure et al., 2012).

Between these E-W trending dextral strike-slip faults, a series of parallel NNE striking sinistral strike-slip faults developed (Fig. 8a; Zhang et al., 2002; Liu et al., 
2010). Unfortunately, the age of the main activity of these faults is not well constrained due to lack of ${ }^{40} \mathrm{Ar} /{ }^{39} \mathrm{Ar}$ ages. Several muscovite and biotite ${ }^{40} \mathrm{Ar} /{ }^{39} \mathrm{Ar}$ ages, of approximately 134-126 Ma (Zhang et al., 2002; Wang and Zheng, 2005), have been obtained from shear zones near the Hongshan-Balihan Fault (Fig. 8a), but they represent the reactivation of the former fault during the formation of an Early Cretaceous metamorphic core complex (Wang and Zheng, 2005). Based on relationships with surrounding geological units, the initial formation of these NNE sinistral strike-slip faults was thought to occur during the Late Paleozoic - Early Mesozoic (IMBGMR, 1991), which is coeval with the E-W trending strike-slip faults. The E-W trending dextral strike-slip faults and NNE sinistral strike-slip faults separate the region into several parallelogram-shaped blocks (Fig. 8a).

\subsection{Regional rotation related to strike-slip movement}

\subsubsection{Origin and age of magnetic remanence}

In order to unravel the effect of the posterior deformation on our paleomagnetic collection, Anisotropy of Magnetic Susceptibility (AMS) measurements were performed before demagnetization. All samples display a weak anisotropy degree with $\mathrm{P}_{\mathrm{J}}<1.10$ (Supplementary Table 3), indicating that they did not experience severe posterior deformation at least at the sampling scale.

The HTC of our paleomagnetic results present both normal and reversed polarities and pass the reversal test in class C (McFadden and McElhinny, 1990). Zircon U-Pb dating of sampled granodiorite yielded a $263 \pm 3$ Ma age (Jiang et al., 2011), which is close to the upper limit of the Permo-Carboniferous Reversed 
Superchron (PCRS), ranging from 320 Ma to $~ 263$ Ma (Cottrell et al., 2008). Considering the error in $\mathrm{U}-\mathrm{Pb}$ dating of this pluton and the inaccuracy of the upper limit of the PCRS, the antipodal normal and reversed polarities may indicate that the Guangxingyuan pluton crystallized just after the PCRS. Thus, the HTC can be considered primary and a corresponding Middle Permian paleomagnetic pole has consequently been calculated at $\lambda=52.7^{\circ} \mathrm{N}, \varphi=245.1^{\circ} \mathrm{E}, \mathrm{dp}=3.3^{\circ}, \mathrm{dm}=6.0^{\circ}$ with $\mathrm{n}=7$ sites.

\subsubsection{Tectonic implications of the paleomagnetic results}

Previous Permian paleomagnetic results reported from both the NCB and the SHB display consistent paleomagnetic poles, indicating that no paleomagnetically detectable relative movement occurred between these blocks since the Permian (Fig. 7e and Supplementary Table 4; Zhao et al., 2013 and references therein). Our Middle Permian pole from the Guangxingyuan pluton (GP) and the poles from both the NCB and SHB are aligned on a small circle centred at the sampling site, showing insignificant latitudinal differences of $2.6^{\circ} \pm 7.1^{\circ}$ between the GP and $\mathrm{NCB}$, and of $2.9^{\circ} \pm 9.6^{\circ}$ between the GP and SHB (Fig. 7e). However, significant clockwise rotations of $66.6^{\circ} \pm 8.7^{\circ}$ and $69.5^{\circ} \pm 11.8^{\circ}$ of GP with respect to the NCB and SHB, respectively, are observed (Fig. 7e). As no paleomagnetically detectable relative rotation occurred between the $\mathrm{NCB}$ and SHB since the Permian, and the Guangxingyuan pluton is located between these two blocks, the clockwise rotation observed in this pluton with respect to these two blocks should have occurred at the local scale. 
During the Late Permian to Late Triassic, the northern margin of the NCB was under a general NNW-SSE shortening regime. The E-W trending dextral strike-slip Xilamulun, Bayan Obo-Chifeng, and Chicheng-Fengning-Longhua faults, which were coeval with magmatic intrusions (X. Zhang et al., 2012; S. Zhang et al., 2012; Wang et al., 2013), accommodated this shortening. The main age of the activity of these strike-slip faults has been constrained to the Late Triassic (Zhang et al., 2002; Ma, 2009; Wang et al., 2013). Although no age constraint for the NNE trending sinistral strike-slip faults is available, the dextral strike-slip movements of these E-W trending faults and the NNW-SSE shortening may have triggered the sinistral movement along these faults. Consequently, the conjugate E-W trending dextral strike-slip faults and the NNE trending sinistral strike-slip faults may have resulted in the clockwise rotations of the parallelogram-shaped blocks between these faults (Fig. 8a), like the book-shelf-style or domino mechanism, which has been observed in numerous strike-slip fault zones, such as in the northern and southern Tibet (Armijo et al., 1989; England and Molnar, 1990), the Zagros belt (Mattei et al., 2012; Isik et al., 2014), and the Alaska range (Cole et al., 1999; Fitzgerald et al., 2013).

6.4 Geodynamic implications on the Triassic tectonics of Central-Eastern Asia

Central-Eastern Asia experienced an important tectonic transition from the completion of the Paleozoic accretion between the NCB and the Mongolian Block (Xiao et al, 2003; Johnson et al., 2008; Xu et al., 2013; Zhao et al., 2013) to the Late Mesozoic intracontinental extension (Meng, 2003; Daoudene et al., 2012). Hence, the Triassic period is a key to decipher the tectonic transition and the evolution of 
Central-Eastern Asia. However, as only a few sedimentary and magmatic rocks are exposed as well as their low degree of investigation, the Triassic tectonic evolution of Central-Eastern Asia is still poorly understood and remains controversial (IMBGMR, 1991; Chen et al., 2000; Li et al., 2007; Zhang et al., 2012; Li et al., 2014). Some authors considered that the Triassic was a late- to post-orogenic period with respect to the $\mathrm{CAOB}$, with syn- to post-orogenic magmatic intrusions (Chen et al., 2000; Zhang et al., 2012) and foreland-style non-marine arid climate deposits (Hendrix et al., 1996; Johnson et al., 2008). During the last several years, large-scale Triassic strike-slip faults were identified in northern China (e.g. Xilamulun Fault, XMF in Fig. 8b), southern Mongolia (e.g. East Gobi Fault, EGF in Fig. 8b; Lamb et al., 2008; Webb et al., 2010; Wang et al., 2013), and Xinjiang (Wang et al., 2008; Choulet et al., 2013). Therefore, an intracontinental shortening and strike-slip shearing dominated tectonic setting was proposed to interpret the Triassic evolution of Central-Eastern Asia (Webb et al., 2010; Wang et al., 2013). Furthermore, spatially dispersed Triassic granitic and syenitic plutons in South Mongolia and the northern margin of the NCB were reported (Chen et al., 2000; Wang et al., 2004; S. Zhang et al., 2012). These plutons were considered to be emplaced in an extensional tectonic setting based on their A-type granitic geochemical affinity. A compatible geodynamic mechanism is needed to explain the coexistence of local extension within a shortening and strike-slip shearing dominated framework.

As the main fault in southeastern Mongolia, the East Gobi Fault (EGF) was identified as a sinistral strike-slip fault with its main shearing activity during the Late 
Triassic (230-210 Ma) as dated by the ${ }^{40} \mathrm{Ar} /{ }^{39} \mathrm{Ar}$ method (Webb et al., 2010). The $\mathrm{XMF}$ and $\mathrm{BCF}$ in the northern margin of the $\mathrm{NCB}$ were also activated during the Late Triassic as discussed above. The contemporaneous activity of these major faults implies that they must be accounted for by a common geodynamic setting. In the Late Permian-Early Triassic, the collision between the NCB and MOB was already completed. Therefore, an intracontinental mechanism will be presented here to explain the Late Triassic shortening and strike-slip shearing. To the north of the MOB, the subduction and closure of the Mongol-Okhotsk Ocean that separated the MOB and the Siberia Block (SIB) may have directly impacted the tectonic evolution of Central-Eastern Asia, even if the time of closure is still debated. According to previous paleomagnetic and geological evidence, Webb et al. (2010) proposed that the oceanic crust subducted beneath the MOB and closed from west to east in the Early Mesozoic. However, based on geological mapping and stratigraphic transition from marine to non-marine deposits, Early Triassic (Zonenshain et al., 1990), or Middle-Late Jurassic (Zorin, 1999) ages have also been suggested. Lastly, a Late Jurassic-Early Cretaceous age has been proposed according to paleomagnetism (e.g., Enkin et al., 1992; Cogné et al., 2005). The southward subduction of the Mongol-Okhotsk Ocean and convergence between the MOB and SIB may produce compression at the northern margin of the MOB, which will be transferred southwards and affect the southeastern part of the MOB (Fig. 8b).

To the south of the NCB, the intracontinental subduction of the South China Block (SCB) underneath the NCB produced ultrahigh pressure metamorphism along 
the Qinling-Dabie Orogen at 242-214 Ma (Rowley et al., 1997; Liu et al., 2006; Zheng, 2008). Once again, this intracontinental subduction is contemporaneous with the ductile shearing activity of the $\mathrm{BCF}$ and $\mathrm{XMF}$ at the northern margin of the $\mathrm{NCB}$. The compression produced by the intracontinental subduction between the NCB and SCB might be transferred northwards and cause large-scale strike-slip movement in the northern margin of the NCB and the southeastern MOB (Fig. 8b). Meanwhile, the closure of the Paleotethys and collision between the Qiangtang Block and Asia also occurred during the Triassic (Kapp et al., 2000; Zhang et al., 2006; Rogers et al., 2008). However, as this block is relatively small compared with the NCB and SCB and is far away from our study area, the impact of this orogenic event on the strike-slip faulting is uncertain.

Considering these compressional events at the northern and southern margins of the Mongolia-North China continental domain (MNCB), we argue that this entire area was under a NNW-SSE compressional stress field in Late Triassic time. The sinistral movement of the EGF and the dextral movement along the XMF and BCF accommodate the NNW-SSE shortening. A consequence of this tectonic pattern is the eastward extrusion of the continental wedge bounded by the EGF and XMF-BCF (Fig. $8 \mathrm{~b})$. This kind of shortening-extrusion scenario is similar to that of the India-Eurasia collision with southeastward extrusion of Sundaland (Tapponnier et al., 1982), or the Arabia-Eurasia collision with westward extrusion of Anatolia (Jackson and McKenzie, 1984; Mattei et al., 2012; Isik et al., 2014). However, the eastward extrusion of the continental wedge bounded by the EGF and XMF-BCF is paleomagnetically 
undetectable as its Permian paleomagnetic pole is consistent with that of the NCB (Fig. 7e).

Meanwhile, the local extension observed within this continental wedge argues for its non-rigid rheological behaviour. It is worth noting that a Late Triassic Metamorphic Core Complex (MCC) has been identified in the Sunidzuoqi area, and that several Late Triassic extension-related granitic and syenitic plutons occurred along the northern margin of the NCB (Fig. 8b; Wang et al., 2004; Davis et al., 2004; Zhang et al., 2012). Extension is only locally observed along the main and secondary strike-slip faults. For example, pull-apart basins and local extensional areas produced by bookshelf rotations of these fault blocks (Fig. 8c).

\section{Conclusions}

Structural analysis, ${ }^{40} \mathrm{Ar}-{ }^{39} \mathrm{Ar}$ dating and paleomagnetic studies have been carried out to investigate the tectonic feature of the Xilamulun Fault (XMF) at the northern margin of the North China Block and to further discuss the geodynamics of Central-Eastern Asia during the Triassic. The structural analysis shows two phases of ductile deformation. The first phase (D1), which displays N-verging E-W trending folds, is related to the Early Paleozoic collisional event between the NCB and the Songliao-Hunshandake Block (SHB). The second phase (D2) displays high-angle foliation and pervasive E-W stretching lineation with kinematic criteria indicative of dextral strike-slip shearing. The ${ }^{40} \mathrm{Ar}-{ }^{39} \mathrm{Ar}$ dating of muscovite from mylonitic granite places the main shearing activity in the Late Triassic. This dextral motion is coeval 
with the dextral strike-slip movements along the Bayan Obo-Chifeng Fault (BCF) and the Chicheng-Fengniang-Longhua Fault zone to the south, and these three faults together constitute a dextral shearing fault system on the northern margin of the NCB during the Late Triassic. The paleomagnetic study carried out on the Guangxingyuan pluton, located between the XMF and the BCF, documents a local clockwise rotation of this pluton with respect to the NCB and the SHB. Our multidisciplinary study suggests a Triassic shortening and strike-slip shearing dominated tectonic setting along the northern margin of the NCB. This dextral strike-slip movement is coeval with the sinistral one along the East Gobi Fault (EGF) in southeastern Mongolia. In the large-scale tectonic framework, a Late Triassic NNW-SSE shortening-eastward extrusion tectonic model of the continental wedge bounded by the XMF-BCF and the EGF for Central-Eastern Asia is proposed here for the first time. This shortening-extrusion tectonic pattern is probably the result of far field forces associated with three Late Triassic convergence domains in East Asia, namely north-directed continental subduction between the NCB and the SCB, collision of the Qiangtang Block and the Qaidam Block, and the southward subduction of the Mongol-Okhotsk Ocean.

Acknowledgments

This work has been funded by the National Key Basic Research Program of China (2013CB429806), and the China Geological Survey Grant (No. 1212011220906). We thank Tong Qinlong and Cheng Shengdong for their support in the field. We gratefully acknowledge the Editor An Yin for handling this paper, 
Dickson Cunningham for reviewing and providing constructive comments that helped us to improve the manuscript.

\section{References}

Armijo, R., Tapponnier, P., Han, T., 1989. Late Cenozoic right-Lateral strike-slip faulting in Southern Tibet. J. Geophys. Res. 94, 2787-2838.

Chen, B., Jahn, B.M., Wilde, S., Xu, B., 2000. Two contrasting Paleozoic magmatic belts in northern Inner Mongolia, China: petrogenesis and tectonic implications. Tectonophysics 328, 157-182.

Chen, J., Chen, Y., Wang, Q., 2008. Synthetic Informational Mineral Resource Prediction: Case Study in Chifeng Region, Inner Mongolia, China. Earth Sci. Frontiers 15, 18-26 (in Chinese with English abstract).

Choulet, F., Chen, Y., Cogné, J-P., Rabillard, A., Wang, B., Lin, W., Faure, M., Cluzel, D., 2013. First Triassic palaeomagnetic constraints from Junggar (NW China) and their implications for the Mesozoic tectonics in Central Asia. J. Asian Earth Sci. 78, 371-394.

Cogné, J. P., Kravchinsky, V. A., Halim, N., Hankard, F., 2005. Late Jurassic-Early Cretaceous closure of the Mongol-Okhotsk Ocean demonstrated by new Mesozoic palaeomagnetic results from the Trans-Baikal area (SE Siberia), Geophys. J. Int. 163, 813-832, doi:10.1111/j.1365-246X.2005.02782.X.

Cole, R.B., Ridgway, K.D., Layer, P.W., Drake, J., 1999. Kinematics of basin development during the transition from terrane accretion to strike-slip tectonics, 
Late Cretaceous-early Tertiary Cantwell Formation, south central Alaska. Tectonics 18, 1224-1244.

Cottrell, R. D., J. A. Tarduno, and J. Roberts (2008), The Kiaman Reversed Polarity Superchron at Kiama: Toward a field strength estimate based on single silicate crystals, Phys. Earth. Planet. Inter. 169, 49-58, doi:10.1016/j.pepi.2008.07.041.

Daoudene, Y., Gapais, D., Ruffet, G., Gloaguen, E., Cocherie, A., Ledru, P., 2012. Syn-thinning pluton emplacement during Mesozoic extension in eastern Mongolia. Tectonics 31, TC3001, doi:10.1029/2011TC002926

Davis, G.A., Xu, B., Zheng, Y.D., Zhang, W.J., 2004. The Sonid Zuoqi metamorphic core complex, Inner Mongolia, China. Earth Sci. Frontiers 11, 134-144.

De Jong, K., Xiao, W.J., Windley, B.F., Masago, H., Lo, C.H., 2006. Ordovician 40Ar/39Ar phengite ages from the blueschist-facies Ondor Sum subduction-accretion complex (Inner Mongolia) and implications for the early Paleozoic history of continental blocks in China and adjacent areas. Am. J. Sci. 306, 799-845.

England, P., and Molnar, P. 1990. Right-lateral shear and rotation as the explanation for strike-slip faulting in east Tibet. Nature, 344, 140-142.

Enkin, R.J., Yang, Z.Y., Chen, Y., Courtillot, V., 1992. Paleomagnetic Constraints on the Geodynamic History of the Major Blocks of China From the Permian to the Present. J. Geophys. Res. 97, B10, 13953-13989. 
Faure, M., Lin, W., Chen, Y., 2012. Is the Jurassic (Yanshanian) intraplate tectonics of North China due to westward indentation of the North China block? Terra Nova 24, 456-466.

Fitzgerald, P.G., Roeske, S.M., Benowitz, J.A., Riccio, S.J., Perry, S.E., Armstrong, P.A., 2013. Alternating asymmetric topography of the Alaska range along the strike-slip Denali fault: Strain partitioning and lithospheric control across a terrane suture zone. Tectonics 33, 1519-1533, doi:10.1002/2013TC003432.

Gong, J., Ji, J., Han, B., Chen, J., Sun, D., Li, B., Zhou, J., Tu. J., Zhong, D., 2012. Early subduction-exhumation and late channel flow of the Greater Himalayan Sequence: implications from the Yadong section in the eastern Himalaya, Int. Geol. Rev. 54(10), 1184-1202.

Hendrix, M.S., Graham, S.A., Amory, J.Y., Badarch, G., 1996. Noyon Uul syncline, southern Mongolia: Lower Mesozoic sedimentary record of the tectonic amalgamation of central Asia. Geol. Soc. Am. Bull. 108, 1256-1274.

Hu, L., Song, H.L., Yan, D.P., Hu, D.G., 2003. The ${ }^{40} \mathrm{Ar} /{ }^{39} \mathrm{Ar}$ geochronology constraint and geological significance of mylonites in Shangyi-Chicheng fault belt on the north of North China Craton. Sci. China, Ser. D: Earth Sci. 46, $1134-1142$.

IMBGMR (Inner Mongolian Bureau of Geology and Mineral Resources), 1991, Regional geology of Inner Mongolian Autonomous Region (in Chinese with English abstract), pp. 1-725. Geological Publishing House, Beijing. 
Isik, V., Uysal, I.T., Caglayan, A., Seyitoglu, G., 2014. The evolution of intraplate fault systems in central Turkey: Structural evidence and Ar-Ar and Rb-Sr age constraints for the Savcili Fault Zone. Tectonics 33, 1875-1899, doi:10.1002/2014TC003565.

Jackson, J., and McKenzie, D.P., 1984. Active tectonics of the Alpine-Himalayan belt between western Turkey and Pakistan. Geophys. J. Royal Astron. Soc. 77, $185-264$

Jian, P., Liu, D., Kröner, A., Windley, B.F., Shi, Y., Zhanf, F., Shi, G., Miao, L., Zhang, W., Zhang, Q., Zhang, L., Ren, J., 2008. Time scale of an early to mid-Paleozoic orogenic cycle of the long-lived Central Asian Orogenic Belt, Inner Mongolia of China: implications for continental growth. Lithos 101, 233-259.

Jiang, X., Liu, Y., Peng, N., Shi, Y., Xu, H., Wei, W., Liu, Z., Zhao, H., Yao, B., 2011. Geochemistry and SHRIMP U-Pb dating of the Guangxingyuan composite pluton in Hexigten Qi, Inner Mongolia and its geological implication. Acta Geologica Sinica 85, 114-128 (in Chinese with English abstract).

Johnson, C. L., Amory, J. A., Zinniker, D., Lamb, M. A., Graham, S. A., Affolter, M., Badarch, G., 2008. Sedimentary response to arccontinent collision, Permian, southern Mongolia, in Formation and Applications of the Sedimentary Record in Arc Collision Zones, edited by A. E. Draut, P. D. Clift, and D. W. Scholl, Geol. Soc. Am. Spec. Paper, 436, 363-390. 
Johnson, C.L., 2004. Polyphase evolution of the East Gobi basin: sedimentary and structural records of Mesozoic-Cenozoic intraplate deformation in Mongolia. Basin Res. 16, 79-99.

Kapp, P., Yin, A., Manning, C.E., Murphy, M., Harrison, T.M., Spurlin, M., Lin, D., Xi-Guang, D., Cun-Ming, W., 2000. Blueschist-bearing metamorphic core complexes in the Qiangtang block reveal deep crustal structure of northern Tibet. Geology 28, 19-22.

Lamb, M.A., Badarch, G., Navratil, T., Poier, R., 2008. Structural and geochronologic data from the Shin Jinst area, eastern Gobi Altai, Mongolia: Implications for Phanerozoic intracontinental deformation in Asia. Tectonophysics 451, 312-330.

Lamb, M.A., Hanson, A.D., Graham, S.A., Badarch, G., Webb, L.E., 1999. Left-lateral sense offset of Upper Proterozoic to Paleozoic features across the Gobi Onon, Tost, and Zuunbayan faults in southern Mongolia and implications for other central Asian faults. Earth Planet. Sci. Lett. 173, 183-194.

Laurent-Charvet, S., Charvet, J., Monié, P., Shu, L.S., 2003. Late Paleozoic strike-slip shear zones in eastern central Asia (NW China): New structural and geochronological data. Tectonics 22, 1009-1034.

Li, J.Y., 2006. Permian geodynamic setting of Northeast China and adjacent regions: closure of the Paleo-Asian Ocean and subduction of the Paleo-Pacific Plate. J. Asian Earth Sci. 26, 207-224.

Li, J.Y., Gao, L.M., Sun, G.H., Li, Y.P., Wang, Y.B., 2007. Shuangjingzi middle Triassic syn-collisional crust-derived granite in the east Inner Mongolia and its 
constraint on the timing of collision between Siberian and Sino-Korean paleo-paltes. Acta Petrol. Sinica 23(3), 565-582 (in Chinese with English abstract).

Li, Y., Zhou, H., Brouwer, F.M., Xiao, W., Wijbrans, J.R., Zhong, Z., 2014. Early Paleozoic to Middle Triassic bivergent accretion in the Central Asian Orogenic Belt: insights from zircon U-Pb dating of ductile shear zones in central Inner Mongolia, China. Lithos 205, 84-111.

Liu, D., Jian, P., Kroner, A., Xu, S., 2006. Dating of prograde metamorphic events deciphered from episodic zircon growth in rocks of the Dabie-Sulu UHP complex, China. Earth Planet. Sci. Lett. 250, 650-666.

Liu, J.F., Li, J.Y., Chi, X.G., Zhao, Z., Hu, Z.C., Feng, Q.W., 2012. Petrogenesis of middle Triassic post-collisional granite from Jiefangyingzi area, southeast Inner Mongolia: Constraint on the Triassic tectonic evolution of the north margin of the Sino-Korean paleoplate. J. Asian Earth Sci. 60, 147-159.

Liu, J.M., Zhao, Y., Sun, Y.L., Li, D.P., Liu, J., Chen, B.L., Zhang, S.H., Sun, W.D., 2010. Recognition of the latest Permian to Early Triassic Cu-Mo mineralization on the northern margin of the North China block and its geological significance. Gondwana Res. 17, 125-134.

Liu, W., Liu, G., Han, J., 2008. Research on Xilamulun fault east extension based on evidence of magnetotelluric sounding data. Global Geol. 27(1), 89-94 (in Chinese with English Abstract). 
Ma, A., 2009. ${ }^{40} \mathrm{Ar} /{ }^{39} \mathrm{Ar}$ dating of muscovite in mylonite of Shang Gang Gang Kun Dui Fault. New evidence for the main stage of Xar Moron River Fault zone. Xinjiang Geology 27, 170-175 (in Chinese with English abstract).

Mattei, M., Cifelli, F., Muttoni, G., Zanchi, A., Berra, F., Mossavvari, F., Eshraghi, S.A., 2012. Neogene block rotation in central Iran: Evidence from paleomagnetic data. Geol. Soc. Am. Bull. 124, 943-956. doi: 10.1130/B30479.1

McFadden, P.L. and McElhinny, M.W., 1990. Classification of the reversal test in paleomagnetism. Geophys. J. Int. 103, 725-729.

Meng, Q.R., 2003. What drove late Mesozoic extension of the northern China-Mongolia tract? Tectonophysics 369, 155-174.

Mueller, J.F., Rogers, J.J.W., Jin, Y.G., Wang, H., Li, W., Chronic, J., Mueller, J.F., 1991. Late Carboniferous to Permian sedimentation in Inner Mongolia, China, and tectonic relationships between north China and Siberia. J. Geol. 99, 251-263.

Pei, F.P., Xu, W.L., Yang, D.B., Zhao, Q.G., Liu, X.M., Hu, Z.C., 2007. Zircon U-Pb geochronology of basement metamorphic rocks in the Songliao Basin. Chinese Sci. Bull. 52, 942-948.

Roger, F., Jolivet, M., Malavieille, J., 2008. Tectonic evolution of the Triassic fold belts of Tibet. CR Geosci. 340, 180-189.

Rowley, D.B., Xue, F., Tucker, R.D., Peng, Z.X., Baker, J., Davis, A., 1997. Ages of ultrahigh pressure metamorphism and protolith orthogneisses from the eastern Dabie Shan: U/Pb zircon geochronology. Earth Planet. Sci. Lett. 151, 191-203. 
Shi, G., Faure, M., Xu, B., Zhao, P., Chen, Y., 2013. Structural and kinematic analysis of the Early Paleozoic Ondor Sum-Hongqi mélange belt, eastern part of the Altaids (CAOB) in Inner Mongolia, China. J. Asian Earth Sci. 66, 123-139.

Tang, K., 1990. Tectonic development of Paleozoic fold belts at the north margin of the Sino-Korean craton. Tectonics 9, 249-260.

Tang, K.D. and Yan, Z.Y., 1993. Regional metamorphism and tectonic evolution of the Inner Mongolian suture zone. J. Metamorph. Geol. 11, 511-522.

Tapponnier, P., Peltzer, G., Ledain, A.Y., Armijo, R., Cobbold, P.R. 1982. Propagating extrusion tectonics in Asia: New insights from simple experiments with plasticine. Geology 10, 611-616.

Wang, T., Guo, L., Zheng, Y., Donskaya, T., Gladkochub, D., Zeng, L., Li, J., Wang, Y., Mazukabzov, A., 2012. Timing and processes of late Mesozoic mid-lower-crustal extension in continental NE Asia and implications for the tectonic setting of the destruction of the North China Craton: Mainly constrained by zircon $\mathrm{U}-\mathrm{Pb}$ ages from metamorphic core complexes. Lithos 154, 315-345.

Wang, T., Zheng, Y., Li, T., Gao, Y., 2004. Mesozoic granitic magmatism in extensional tectonics near the Mongolian border in China and its implications for crustal growth. J. Asian Earth Sci. 23, 715-729.

Wang, X. And Zheng, Y., 2005. ${ }^{40} \mathrm{Ar} /{ }^{39} \mathrm{Ar}$ age constraints on the ductile deformation of the detachment system of the Louzidian core complex, southern Chifeng, China. Geol. Rev. 51(5), 574-582 (in Chinese with English abstract). 
Wang, Y., Li, J., Sun, G., 2008. Postcollisional Eastward Extrusion and Tectonic Exhumation along the Eastern Tianshan Orogen, Central Asia: Constraints from Dextral Strike-Slip Motion and ${ }^{40} \mathrm{Ar} /{ }^{39} \mathrm{Ar}$ Geochronological Evidence. J. Geol., $116,599-618$.

Wang, Y., Zhang, F.Q., Zhang, D.W., Miao, L.C., Li, T.S., Xie, H.Q., Meng, Q.R., Liu, D.Y., 2006. Zircon SHRIMP U-Pb dating of meta-diorite from the basement of the Songliao Basin and its geological significance. Chin. Sci. Bull. 51, $1877-1883$

Wang, Y., Zhou, L., Zhao, L., 2013. Cratonic reactivation and orogeny: An example from the northern margin of the North China Craton. Gondwana Res. 24, 1203-1222.

Webb, L.E., Johnson, C.L., 2006. Tertiary strike-slip faulting in southeastern Mongolia and implications for Asian tectonics. Earth Planet. Sci. Lett. 241, 323-335.

Webb, L.E., Johnson, C.L., Minjin, C., 2010. Late Triassic sinistral shear in the East Gobi Fault Zone, Mongolia. Tectonophysics 495, 246-255.

Wu, F.Y., Lin, J.Q., Wilde, S.A., Sun, D.Y., Yang, J.H., 2005. Nature and significance of the Early Cretaceous giant igneous event in eastern China. Earth Planet. Sci. Lett. 233, 103-119.

Wu, H., Zhang, L., Wan, B., Chen, Z., Zhang, X., Xiang, P., 2011. Geochronological and geochemical constraints on Aolunhua porphyry $\mathrm{Mo}-\mathrm{Cu}$ deposit, northeast China, and its tectonic significance. Ore Geol. Rev. 43, 78-91. 
Xiao, W.J., Windley, B., Hao, J., Zhai, M.G., 2003. Accretion leading to collision and the Permian Solonker suture, Inner Mongolia, China: termination of the Central Asian Orogenic Belt. Tectonics 22, 1069-1089.

Xu, B., Charvet, J., Chen, Y., Zhao, P., Shi, G., 2013. Middle Paleozoic convergent orogenic belts in western Inner Mongolia (China): framework, kinematics, geochronology and implications for tectonic evolution of the Central Asian Orogenic Belt. Gondwana Res. 23, 1342-1364.

Xu, B., Charvet, J., Zhang, F.Q., 2001. Primary study on petrology and geochronology of the blueschist in Sonid Zuoqi, northern Inner Mongolia. Chin. J. Geol. 36, 424-434 (in Chinese with English abstract).

Xu, B., Zhao, P., Wang, Y.Y., Liao, W., Luo, Z.W., Bao, Q.Z., Zhou, Y.H., 2015. The pre-Devonian tectonic framework of Xing'an-Mongolia orogenic belt (XMOB) in north China. Journal of Asian Earth Sciences 97, 183-196.

Zeng, Q., Yang, J., Zhang, Z., Liu, J., Duan, X., 2013. Petrogenesis of the Yangchang Mo-bearing granite in the Xilamulun metallogenic belt, NE China: geochemistry, zircon U-Pb ages and Sr-Nd-Pb isotopes. Geol. J. doi: 10.1002/gj.2481

Zhang, K.J., Cai, J.X., Zhang, Y.X., Zhao, T.P., 2006. Ecologites from central Qiangtang, northern Tibet (China) and tectonic implications. Earth Planet. Sci. Lett. 245, 722-729.

Zhang, L, Wu, H., Wan, B., Chen, Z., 2009. Ages and geodynamic settings of Xilamulun Mo-Cu metallogenic belt in the northern part of the North China Craton. Gondwana Res. 16, 243-254. 
Zhang, S.H., Zhao, Y., Song, B., Hu, J.M., Liu, S.W., Yang, Y.H., Chen, F.K., Liu, X.M., Liu, J., 2009. Contrasting Late Carboniferous and Late Permian-Middle Triassic intrusive suites from the northern margin of the North China craton: Geochronology, petrogenesis, and tectonic implications. Geol. Soc. Am. Bull. 121, 181-200.

Zhang, S.H., Zhao, Y., Ye, H., Hou, K.J., Li, C.F., 2012. Early Mesozoic alkaline complexes in the northern North China Craton: Implications for cratonic lithospheric destruction. Lithos 155, 1-18.

Zhang, W., Jian, P., Kroner, A., Shi, Y., 2013. Magmatic and metamorphic development of an early to mid-Paleozoic continental margin arc in the southernmost Central Asian Orogenic Belt, Inner Mongolia, China. J. Asian Earth Sci. 72, 63-74.

Zhang, X., Li, T., Pu, Z., Wang, H., 2002. 40Ar-39Ar ages of the Louzidian-Dachengzi ductile shear zone near Chifeng, Inner Mongolia and their tectonic significance. Chin. Sci. Bull. 47, 1292-1297.

Zhang, X., Wang, H., Li, T., 2005. ${ }^{40} \mathrm{Ar} /{ }^{39} \mathrm{Ar}$ geochronology of the Faku tectonites: Implications for the tectonothermal evolution of the Faku block, northern Liaoning. Sci. China Ser. D: Earth Sci. 48(5), 601-612.

Zhang, X., Xue, F., Yuan, L., Ma, Y., Wilde, S.A., 2012. Late Permian appinite-granite complex from northwestern Liaoning, North China Craton: Petrogenesis and tectonic implications. Lithos 155, 201-217. 
Zhang, X.H., Zhang, H.F., Tang, Y.J., Wilde, S.A., Hu, Z.C., 2008. Geochemistry of Permian bimodal volcanic rocks from Central Inner Mongolia, North China: Implication for tectonic setting and Phanerozoic continental growth in Central Asian Orogenic Belt. Chem. Geol. 249, 261-281.

Zhao, P., Chen, Y., Xu, B., Faure, M., Shi, G., Choulet, F., 2013. Did the Paleo-Asian Ocean between North China Block and Mongolia Block exist during the late Paleozoic? First paleomagnetic evidence from central-eastern Inner Mongolia, China. J. Geophys. Res.: Solid Earth 118, 1873-1894.

Zhao, P., Xu, B., Tong, Q., Chen, Y., Faure, M., 2015. Sedimentological and geochronological constraints on the Carboniferous evolution of central Inner Mongolia, southeastern Central Asian Orogenic Belt: Inland sea deposition in a post-orogenic setting. Gondwana Research, doi: 10.1016/j.gr.2015.01.010

Zhao, P., Jahn, B.M., Xu, B., Geochemistry, geochronology and Hf isotopic studies of peralkaline-alkaline intrusions along the north margin of North China Craton: Middle Permian extension and its tectonic significance for the Southeastern Central Asian Orogenic Belt. in preparation.

Zheng, Y.F., 2008. A perspective view on ultrahigh-pressure metamorphism and continental collision in the Dabie-Sulu orogenic belt. Chin. Sci. Bull. 53, 3081-3104.

Zonenshain, L. P., Kuzmin, M. I., Natapov, L. M., 1990. Tectonics of Lithosphere Plates of the Territory of the USSR (in Russian), Nedra, Moscow, vol. 1, pp. 328. 
Zorin, Y.A., 1999. Geodynamics of the western part of the Mongolia-Okhotsk collisional belt, Trans-Baikal region (Russia) and Mongolia. Tectonophysics 306, $33-56$.

Figure caption:

Figure 1. (a) Schematic tectonic map of the Central Asian Orogenic Belt in Central-Eastern Asia (modified after Sengor et al., 1993 and Han et al., 2010) with the location of Fig. 1b in a box. (b) Tectonic map of Inner Mongolia showing the two Silurian-Devonian orogenic belts (Northern Orogen and Southern Orogen) that separated the three continental blocks of Xing'an-Airgin Sum Block, Songliao-Hunshandake Block and North China Block from north to south, respectively (modified after Jian et al., 2008 and Xu et al., 2013).

Figure 2. (a) Geological map along Xilamulun Fault from Shuangjingzi to Balinqiao (modified after IMBGMR, 1976). (b) Two cross sections across the Xilamulun Fault. (c) foliation and lineation relative to ductile strike-slip movement of Xilamulun Fault (lower hemisphere projection).

Figure 3. Field (a-g) and microscope (h-j) photos showing the kinematics of Xilamulun Fault. (a) N-verging E-W trending fold related the D1 deformation. (b) View of fault plane which cut the mountains into subvertical cliffs with horizontal 
slicken lines and steps. (c) Interpretative diagram showing the kinematic patterns in mylonite along Xilamulun Fault (the protolith is $\mathrm{O}-\mathrm{S}_{1}$ metasedimentary-metavolcanic rocks). (d) Intersecting surface showing elongated and squashed pebbles. (e) Asymmetric fold with vertical axis presenting dextral strike-slip shearing. (f) Centimeter-scale asymmetric $\sigma$-type feldspar grain. (g) S-C fabrics (the protolith is $\mathrm{P}_{1-2}$ granite). (h) millimeter-scale asymmetric $\sigma$-type feldspar grain (the protolith is $\mathrm{P}_{1}$ volcaniclastic rocks). (i) millimeter-scale asymmetric $\sigma$-type quartz grain with tails of biotite (the protolith is $\mathrm{O}-\mathrm{S}_{1}$ metavolcanic rocks). (j) "mica fish" structure (the protolith is $\mathrm{P}_{1-2}$ granite).

Figure 4. Block diagram showing the kinematics of the Xilamulun Fault. The folding of $\mathrm{O}-\mathrm{S}_{1}$ gneiss and schist maybe related to the orogenic event occurred at the end of Early Paleozoic. The pervasive E-W lineations can be observed from all pre-Jurassic units along Xilamulun Fault, showing the Late Triassic E-W dextral shearing. The ductile strike-slip fault zone was covered unconformably by the Middle Jurassic conglomerate, postdating the strike-slip movement.

Figure 5. ${ }^{40} \mathrm{Ar}-{ }^{39} \mathrm{Ar}$ geochronological result of Xilamulun strike-slip fault. (a) Apparent ${ }^{40} \mathrm{Ar}-{ }^{39} \mathrm{Ar}$ age spectra of this study. Box heights and quoted errors are $2 \sigma$; (b) Isochron age of this study; (c) Zircon U-Pb age of syn-strike-slip granite along Xilamulun Fualt, and muscovite ${ }^{40} \mathrm{Ar}^{39} \mathrm{Ar}$ age of mylonite and granitic gneiss along Xilamulun Fault. References are (1) Li et al., 2007; (2) Ma et al., 2009; (3) This study. 
Figure 6. (a) Geological map of the area south of Hexigten, showing the location of Guangxingyuan pluton where paleomagnetic collection was carried out (modified after IMBGMR, 1976). (b-d) Magnetic mineralogical studies of Guangxingyuan pluton. (b) Result of thermomagnetic Curie temperature analyses. (c) Isothermal magnetization result. (d) Representative hysteresis loop. These three analysis show that titanium-poor magnetite is the main magnetic carrier.

Figure 7. Measurement results of Guangxingyuan pluton. (a-c) Orthogonal projection in in-situ coordinates, showing antipodal normal and reversed polarities. (d) Equal-area stereoplot for high temperature components. Hollow (black) circles represent reversal (normal) polarities of site-mean direction. The reversal polarity site is reversed into normal to calculate the mean direction (star). (e) Comparison of paleomagnetic pole of Guangxingyuan pluton (GP) with respective to those of North China Block (NCB) and Songliao-Hunshandake Block (SHB) in equal-area projection, showing a significant clockwise rotation of GP relative to NCB and SHB.

Figure 8. Kinematic summary of the possible roles of strike-slip faults across Central-Eastern Asia. (a) To the north margin of NCB, two main W-E trending dextral strike-slip faults (Xilamulun Fault and Bayan Obo-Chifeng Fault), and subordinate W-E dextral and NE-SW sinistral faults, cut up the region into several parallelogram-shaped microblocks. The ${ }^{40} \mathrm{Ar}-{ }^{39} \mathrm{Ar}$ age of the deformed mica in the 
mylonite along these faults indicate that the main activity occurred during the Late Triassic. The displacement along these contemporaneous faults can be ascribed to a NNW-SSE regional shortening that also causes the dextral and sinistral movements of W-E and NNE-SSW trending faults, respectively. The shearing is accompanied by a clockwise rotation of the parallelogram-shaped microblocks. (b) At the central-eastern Asia scale, during the Late Triassic, the East Gobi Fault (EGF) displays a sinistral strike-slip movement, while the Chicheng-Fengning-Longhua Fault (CFLF), the Bayan Obo-Chifeng Fault (BCF), and the Xilamulun Fault (XMF) at the north margin of NCB show dextral strike-slip movements. This kind of conjugate shearing can be variously ascribed to the NNW-SSE shortening due to i) southeastward subduction of the Mongol-Okhotsk Ocean, ii) intracontinental subduction between NCB and SCB, and iii) the collision between the Qiangtang Block and Asia in the Late Triassic. The NNW-SSE shortening also caused the eastward extrusion of the continental wedge bounded by EGF and BCF. Under this shortening-extrusion regime, local extension, represented by metamorphic core complex (MCC), and syntectonic plutons can be observed within the wedge. This complex tectonic pattern shows that this continental crust wedge did not behave as a rigid block. The fault systems in the northern margin of NCB, and in Mongolia are modified from Zhang et al. (2009); Wu et al. (2011); Zeng et al. (2013); Wang et al. (2013), and from Webb et al., (2010), respectively. The location of sutures is modified from Webb et al., 2010. (c) Simplified bookshelf model showing how the shortening and dextral shearing may cause a bookshelf structure with clockwise block rotation accommodated by sinistral faults and local 
opening of voids allowing magma emplacement. 


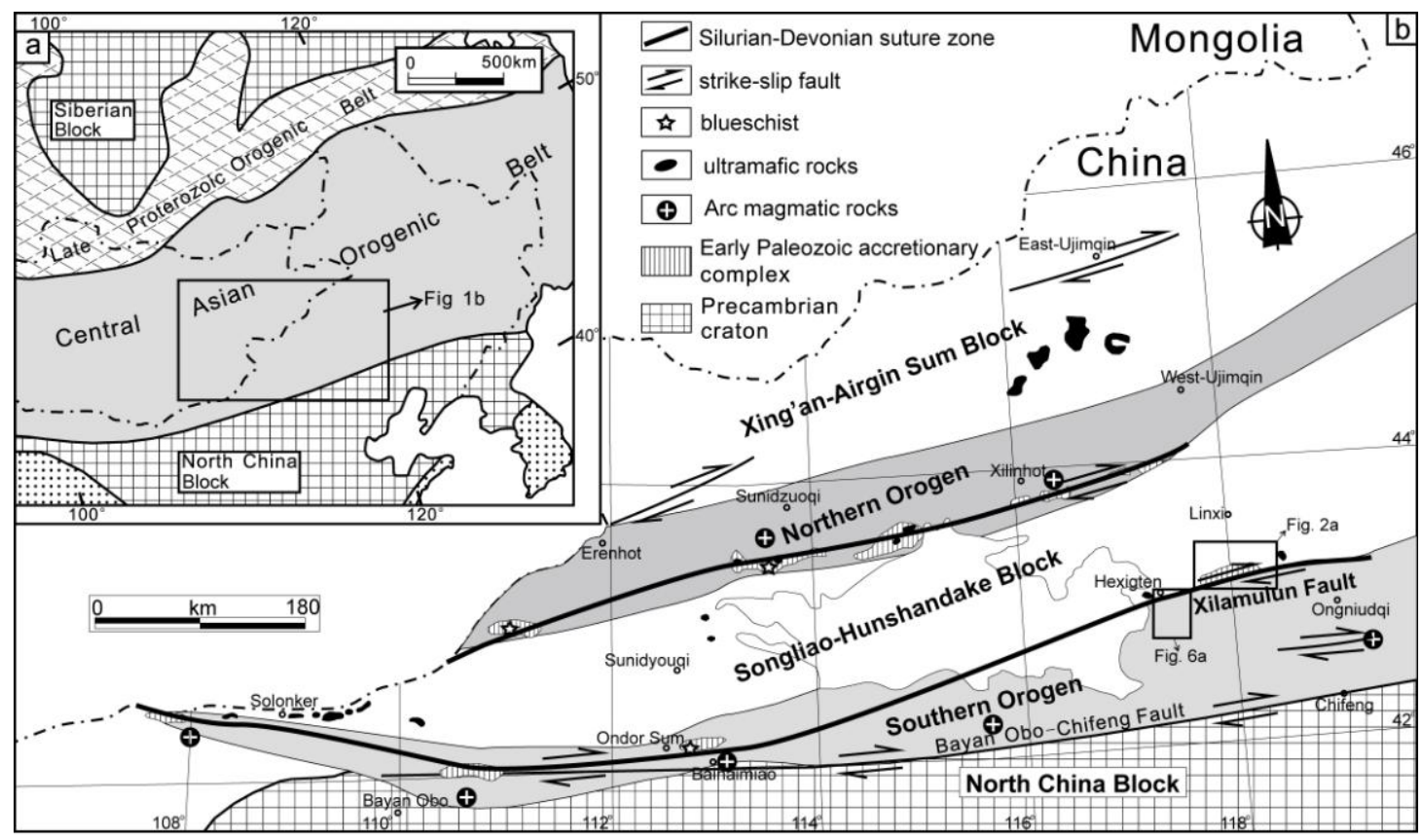

Figure 1. (a) Schematic tectonic map of the Central Asian Orogenic Belt in Central-Eastern Asia (modified after Sengor et al., 1993 and Han et al., 2010) with the location of Fig. $1 b$ in a box. (b) Tectonic map of Inner Mongolia showing the two Silurian-Devonian orogenic belts (Northern Orogen and Southern Orogen) that seperated the three continental blocks of Xing'an-Airgin Sum Block, Songliao-Hunshandake Block and North China Block from north to south, respectively (modified after Jian et al., 2008 and Xu et al., 2013). 

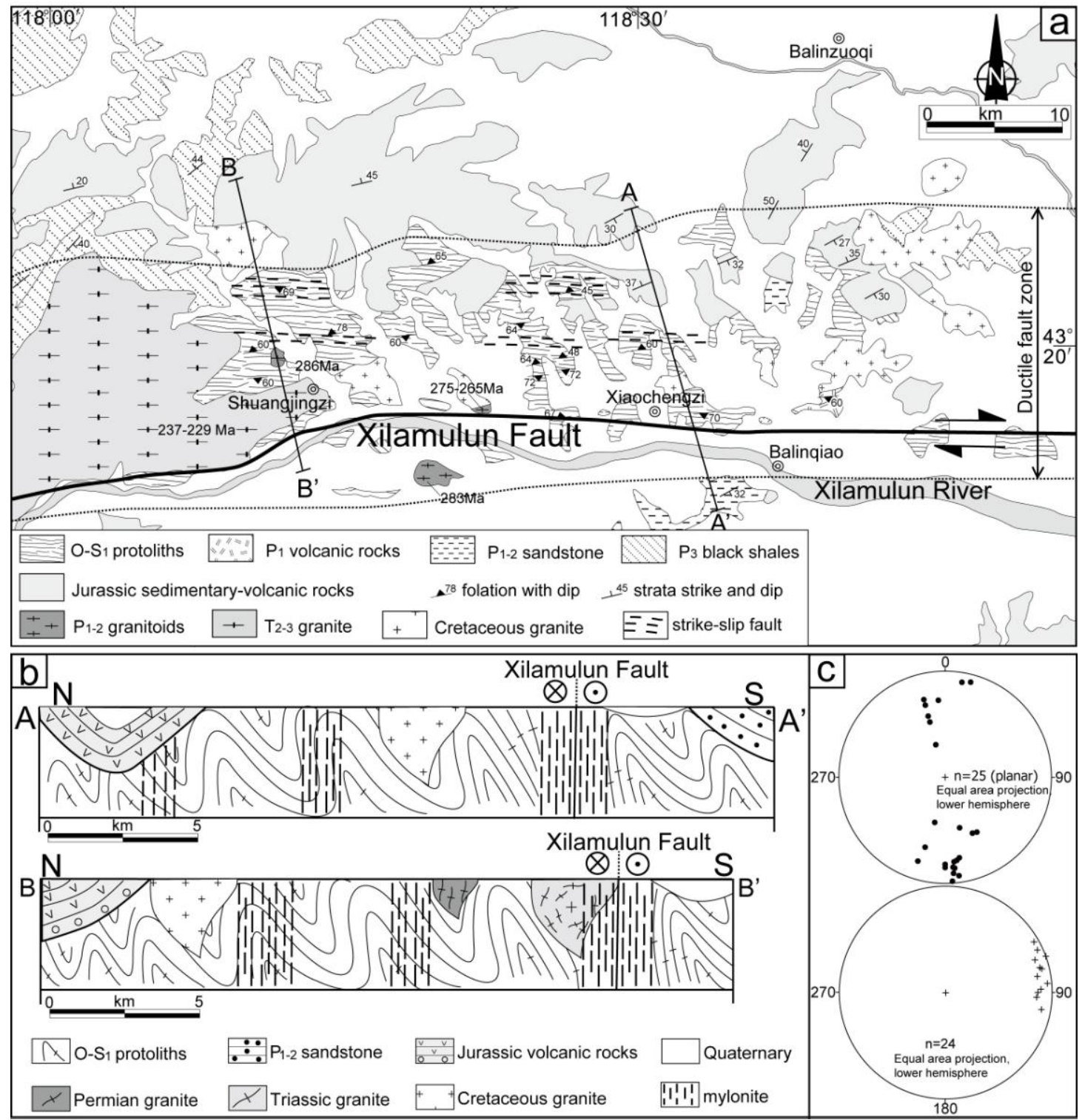

Figure 2. (a) Geological map along Xilamulun Fault from Shuangjingzi to Balinqiao (modified after IMBGMR, 1976). (b) Two cross sections across the Xilamulun Fault. (c) foliation and lineation relative to ductile strike-slip movement of Xilamulun Fault (lower hemisphere projection). 


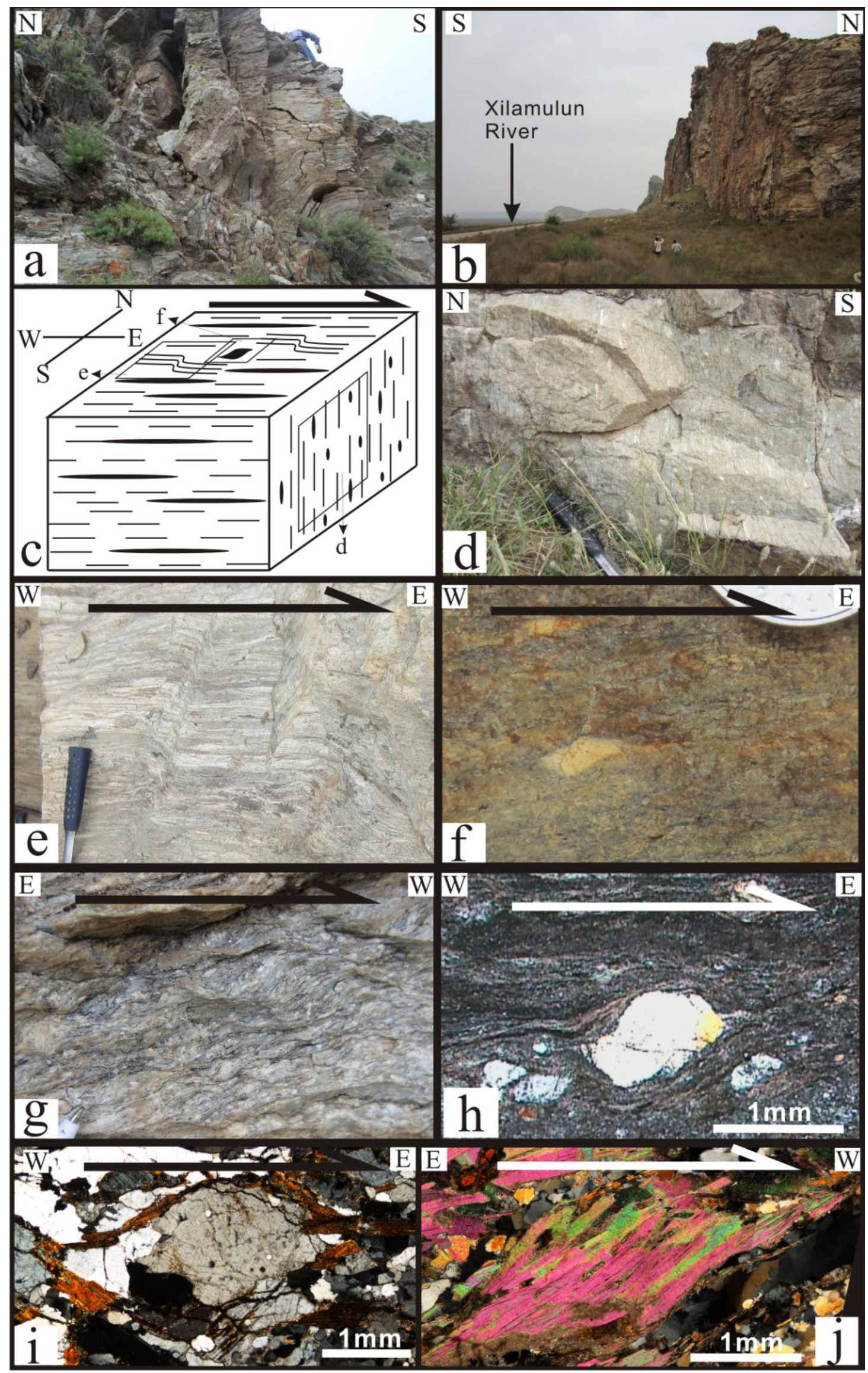


Figure 3. Field (a-g) and microscope (h-j) photos showing the kinematics of Xilamulun Fault. (a) N-verging E-W trending fold related the D1 deformation. (b) View of fault plane which cut the mountains into subvertical cliffs with horizontal slicken lines and steps. (c) Interpretative diagram showing the kinematic patterns in mylonite along Xilamulun Fault (the protolith is $\mathrm{O}-\mathrm{S}_{1}$ metasedimentary-metavolcanic rocks). (d) Intersecting surface showing elongated and squashed pebbles. (e) Asymmetric fold with vertical axis presenting dextral strike-slip shearing. (f) Centimeter-scale asymmetric $\sigma$-type feldspar grain. (g) $\mathrm{S}$-C fabrics (the protolith is $\mathrm{P}_{1-2}$ granite). (h) millimeter-scale asymmetric $\sigma$-type feldspar grain (the protolith is $\mathrm{P}_{1}$ volcaniclastic rocks). (i) millimeter-scale asymmetric $\sigma$-type quartz grain with tails of biotite (the protolith is $\mathrm{O}-\mathrm{S}_{1}$ metavolcanic rocks). (j) "mica fish" structure (the protolith is $\mathrm{P}_{1-2}$ granite). 


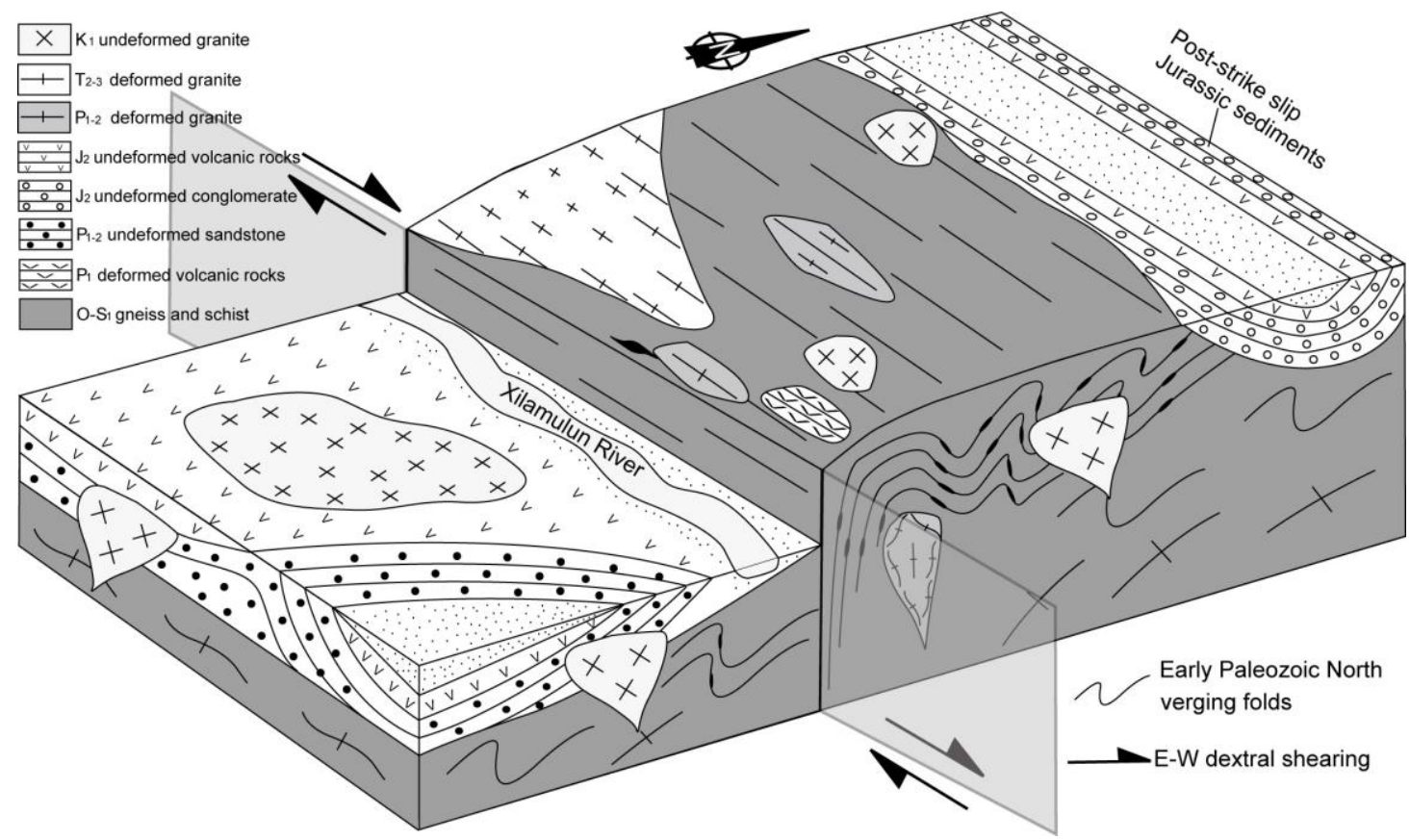

Figure 4. Block diagram showing the kinematics of the Xilamulun Fault. The folding of O-S gneiss and schist maybe related to the orogenic event occurred at the end of Early Paleozoic. The pervasive E-W lineations can be observed from all pre-Jurassic units along Xilamulun Fault, showing the Late Triassic E-W dextral shearing. The ductile strike-slip fault zone was covered unconformably by the Middle Jurassic conglomerate, postdating the strike-slip movements. 

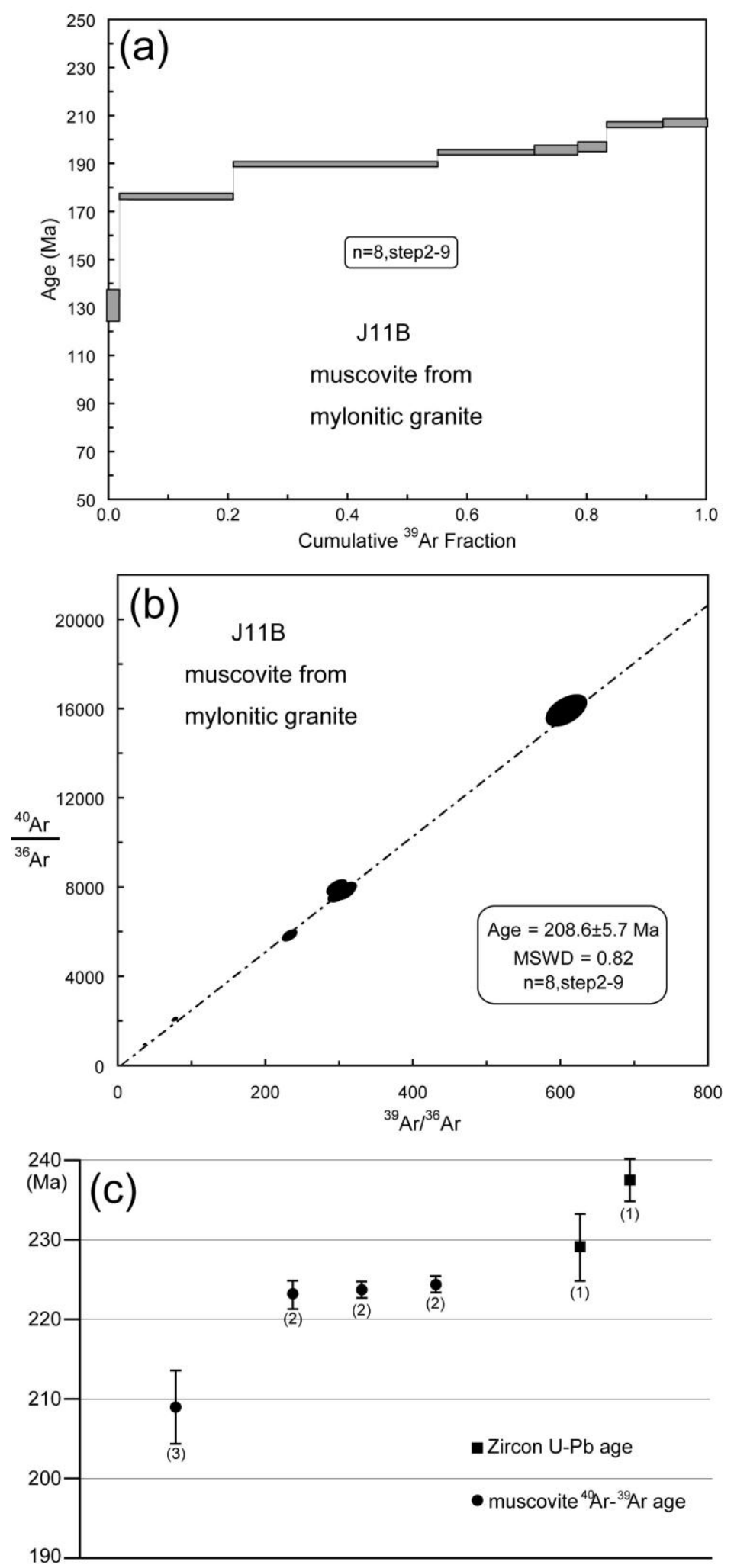

Figure 5. ${ }^{40} \mathrm{Ar}-{ }^{39} \mathrm{Ar}$ geochronological result of Xilamulun strike-slip fault. (a) Apparent ${ }^{40} \mathrm{Ar}-{ }^{39} \mathrm{Ar}$ age spectra of this study. Box heights and quoted errors are $2 \sigma$; (b) Isochron age of this study; (c) Zircon U-Pb age of syn-strike-slip granite along Xilamulun Fualt, and muscovite ${ }^{40} \mathrm{Ar}^{39}{ }^{39} \mathrm{Ar}$ age of mylonite and granitic gneiss along Xilamulun Fault. References are (1) Li et al., 2007; (2) Ma et al., 2009; (3) This study. 

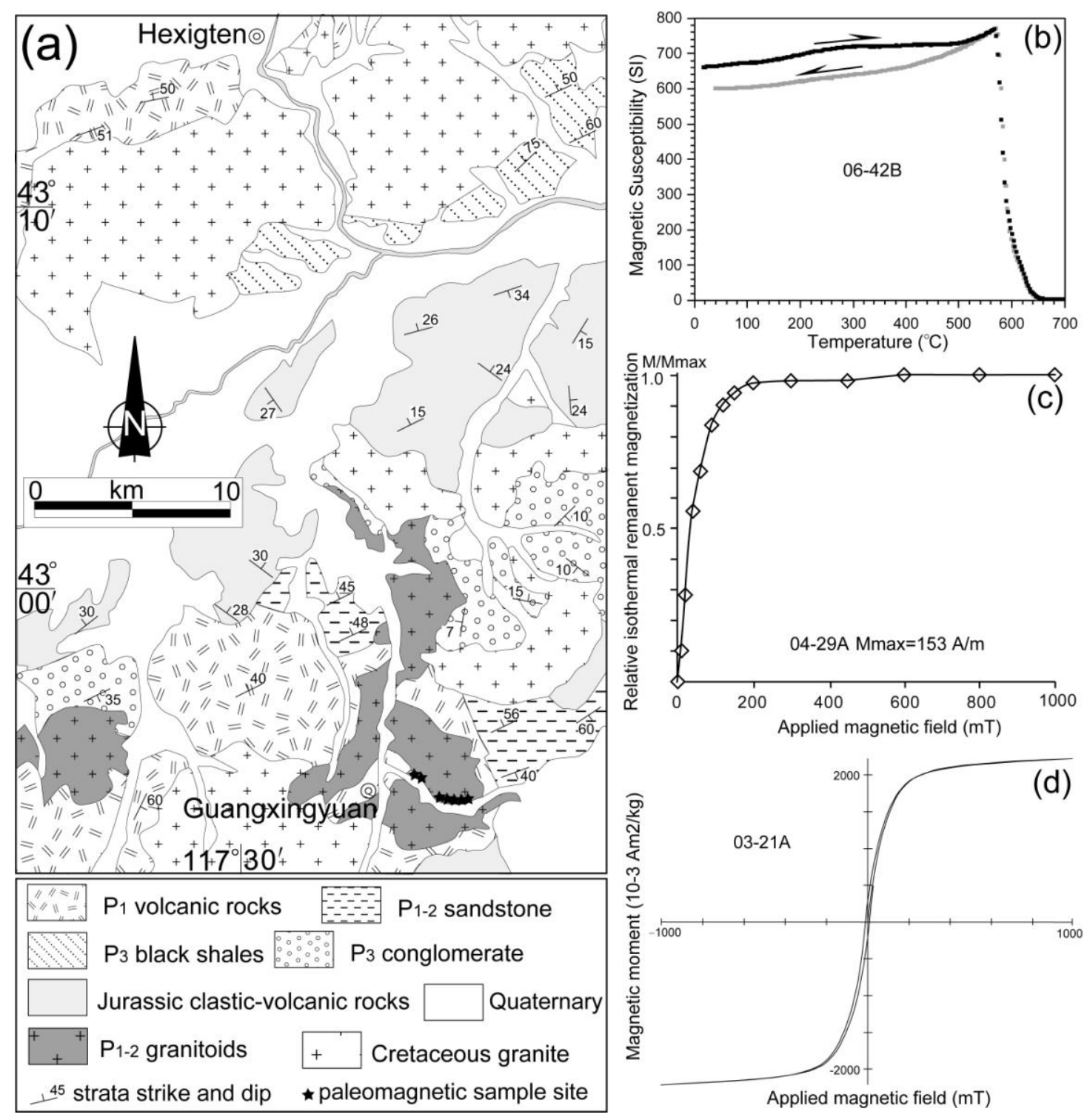

Figure 6. (a) Geological map of the area south of Hexigten, showing the location of Guangxingyuan pluton where paleomagnetic collection was carried out (modified after IMBGMR, 1976). (b-d) Magnetic mineralogical studies of Guangxingyuan pluton. (b) Result of thermomagnetic Curie temperature analyses. (c) Isothermal magnetization result. (d) Representative hysteresis loop. These three analysis showing titanium-poor magnetite as the main magnetic carrier. 


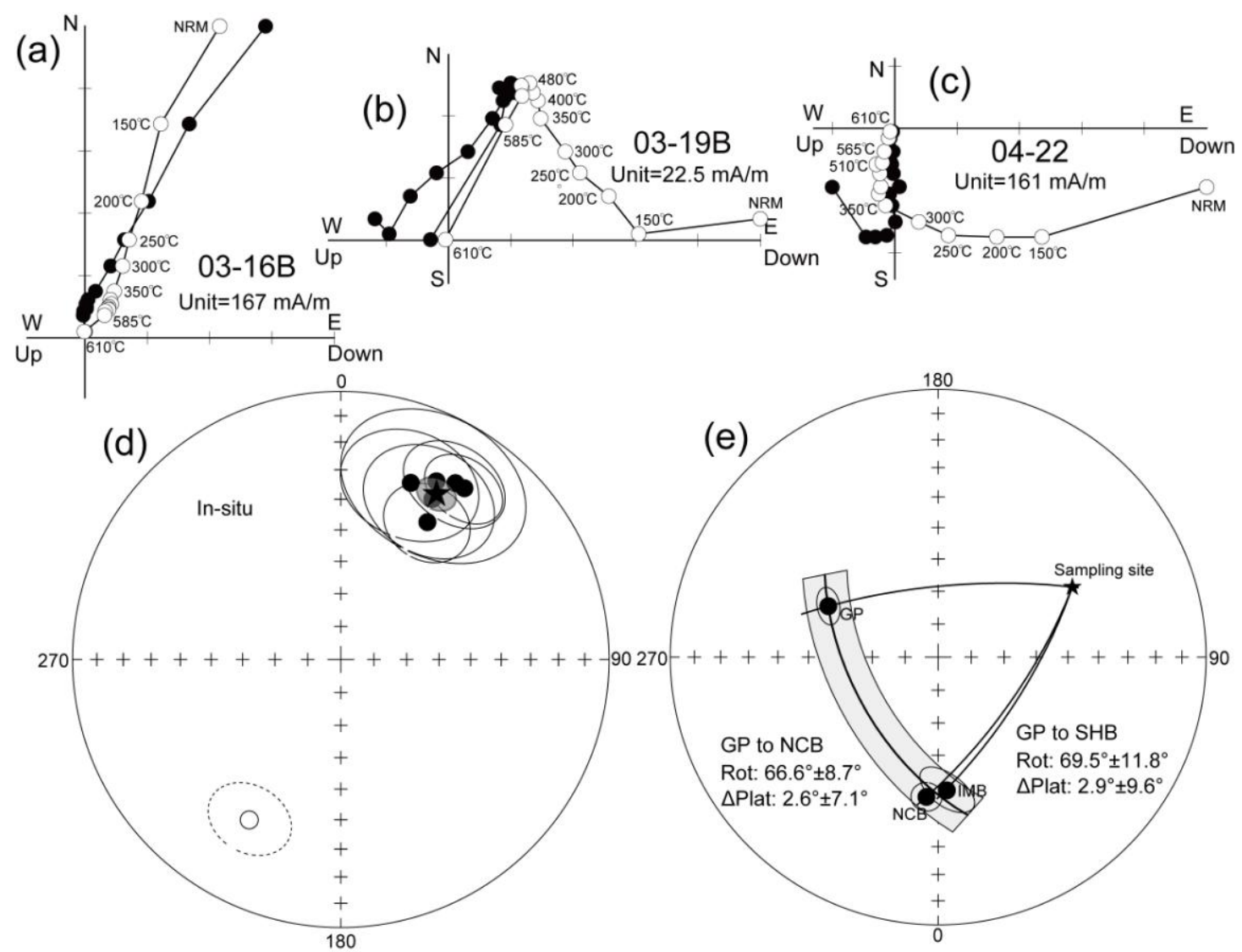

Figure 7. Measurement results of Guangxingyuan pluton. (a-c) Orthogonal projection in in-situ coordinates, showing antipodal normal and reversed polarities. (d) Equal-area stereoplot for high temperature components. Hollow (black) circles in represent reversal (normal) polarities of site-mean direction. These three reversal polarity sites are reversed into normal to calculated the mean direction (star). (e) Comparison of paleomagnetic pole of Guangxingyuan pluton (GP) with respective to those of North China Block (NCB) and Songliao-Hunshandake Block (SHB) in equal-area projection, showing a significant clockwise rotation of GP relative to NCB and SHB. 


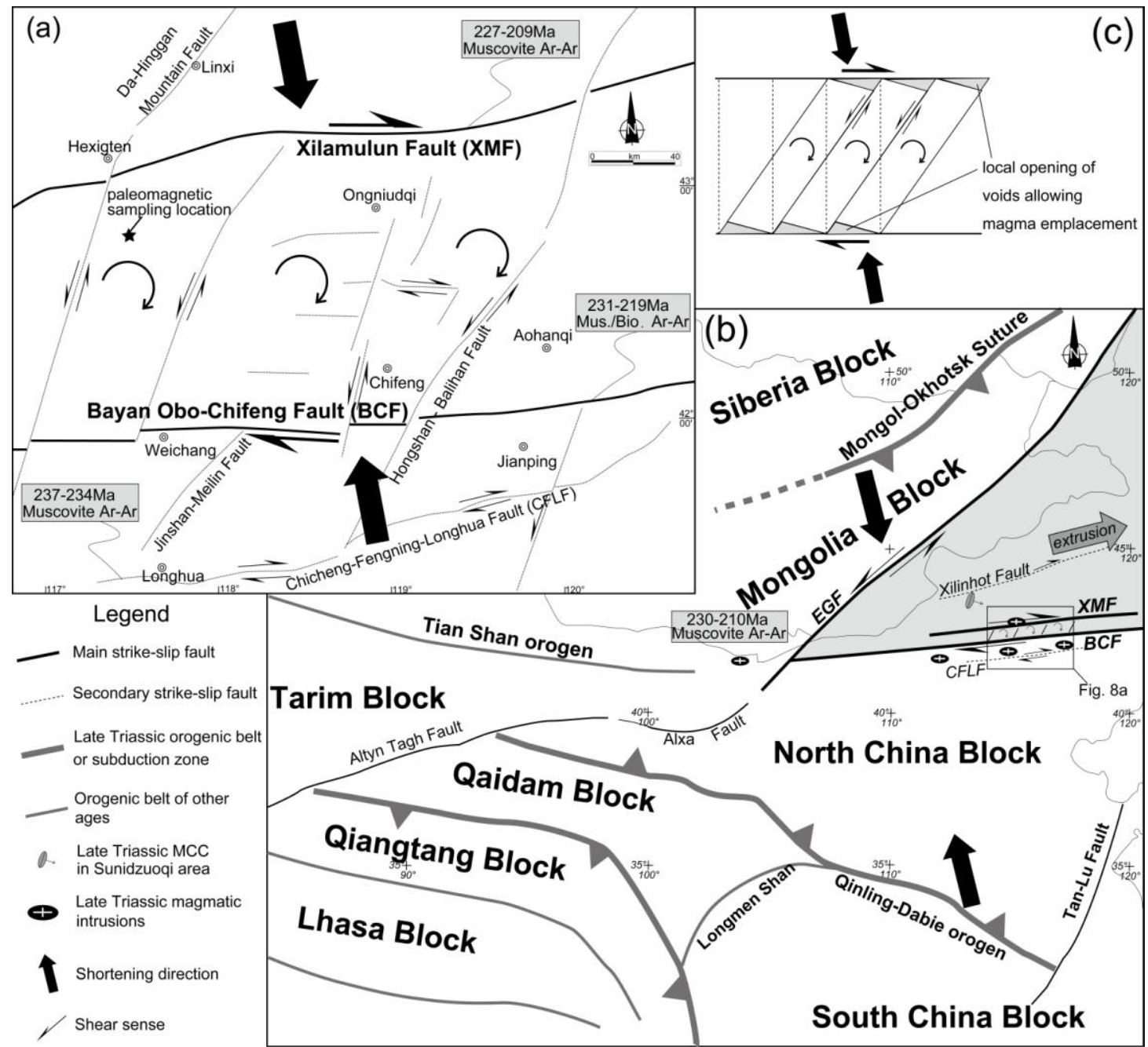

Figure 8. Kinematic summary of the possible roles of strike-slip faults across Central-Eastern Asia. (a) To the north margin of NCB, two main W-E trending dextral strike-slip faults (Xilamulun Fault and Bayan Obo-Chifeng Fault), and subordinate W-E dextral and NE-SW sinistral faults, cut up the region into several parallelogram-shaped microblocks. The ${ }^{40} \mathrm{Ar}-{ }^{39} \mathrm{Ar}$ age of the deformed mica in the mylonite along these faults indicate that the main activity occurred during the Late Triassic. The displacement along these contemporaneous faults can be ascribed to a NNW-SSE regional shortening that also causes the dextral and sinistral movements of W-E and NNE-SSW trending faults, respectively. The shearing is accompanied by a clockwise rotation of the parallelogram-shaped microblocks. (b) At the central-eastern 
Asia scale, during the Late Triassic, the East Gobi Fault (EGF) displays a sinistral strike-slip movement, while the Chicheng-Fengning-Longhua Fault, the Bayan Obo-Chifeng Fault (BCF), and the Xilamulun Fault (XMF) at the north margin of NCB show dextral strike-slip movements. This kind of conjugate shearing can be variously ascribed to the NNW-SSE shortening due to i) southeastward subduction of the Mongol-Okhotsk Ocean, ii) intracontinental subduction between NCB and SCB, and iii) the collision between the Qiangtang Block and Asia in the Late Triassic. The NNW-SSE shortening also caused the eastward extrusion of the continental wedge bounded by EGF and BCF. Under this shortening-extrusion regime, local extension, represented by metamorphic core complex (MCC), and syntectonic plutons can be observed within the wedge. This complex tectonic pattern shows that this continental crust wedge did not behave as a rigid block. The fault systems in the northern margin of NCB, and in Mongolia are modified from Zhang et al. (2009); Wu et al. (2011); Zeng et al. (2013); Wang et al. (2013), and from Webb et al., (2010), respectively. The location of sutures is modified from Webb et al., 2010. 